longed to what was known as the "old men's class in gymnastics" at the latter, and for 17 years, when in town, attended it regularly five days in the week! The doctor was always much interested in the Latin classics, having received a thorough drill therein in his youth, and reading them readily in the original. His favorite English novelist was Thackeray. Of late years he had spent as much time as possible in the open air, riding horseback, walking and supervising his farm in Dedham, in which he took the greatest interest. His long life was due in no slight degree to his calm temperament, his philosophical mind, his sensible habits, and the wise regulation of his daily activities. Many might well learn a lesson therefrom.

In 1861 Dr. Cheever married Miss Annie C., daughter of Thaddeus and Sarah (Chamberlain) Nichols of Boston, who survives him, as do four of the six children: Dr. David Cheever of the Harvard Medical School and of the surgical staff of the Peter Bent Brigham Hospital, now in charge of the second Harvard Unit at a British hospital in France; Adeline, wife of Dr. George S. Whiteside of Portland, Oregon, and Misses Alice and Helen Cheever of Boston, the latter well known for her interest in charitable work in this vicinity.

The prominent features of Dr. Cheever's life were character and service. His ideals were sane and noble, his tastes refined, his standards were high, and his daily life consistent therewith. He was truth and justice personified. His devotion to duty was limited only by his time and strength. Swayed less by impulse than most men, his judgment was sound and his advice dependable. He was a tower of strength and comfort in time of trouble. Kindly in his feelings, lenient in his criticism, just in his estimates of people, he was ready at all times to help his fellow men. For half a century he has been a guide and an inspiration to his fellows. His life has been a benison to his family, to his patients and to his friends. A fine type of man, a public spirited citizen, an eminent surgeon, an honor to his.profession and to his alma mater, an occupant of many important positions and never found wanting, he will be missed in the community, and the void in the hearts of his family and his friends will never be filled.

George W. GAY, M.D.

\section{SUMNER EDWARDS, M.D.}

The death of SUMNer EDwards, which occurred on January 6,1916, ended suddenly a life of much promise. Edwards was twenty-six years of age and so just entering upon his life's work when the summons came. After spending his boyhood in Bethel, Maine, he entered Bowdoin College for his collegiate training. There he entered very keenly into the college life; he was a member of the Theta Delta Chi fraternity; he was prominent in track athletics, and in his senior year he was president of his class. $\mathrm{He}$ was an excellent student, as shown by his election to the Phi Beta Kappa. He graduated from Bowdoin in 1910 with the A.B. degree. He then spent a year at Hebron Academy, Maine, before entering upon the study of medicine at Harvard. At Harvard, as at Bowdoin, he was active in the student life, being a member of the Innominate, Aesculapian and Boylston Societies and the Phi Rho Sigma Fraternity, and one year president of his class. He graduated in 1915, receiving the M.D. degree cum laude. In a competitive examination in January, 1915, he won a place as medical house-officer at the Peter Bent Brigham Hospital. . About the middle of October, 1915, he came on duty for this work.

In his term at the hospital he was efficient, doing his work exceedingly well. His bearing was modest; he was pleasant in his relations to all of his associates on the hospital staff and to the patients, and so he came to be greatly liked by all in the hospital. His illness began, as did many of the cases of the recent epidemic of grippe, with a high fever and great prostration. In a few days lobar pneumonia developed in one lower lobe of his lung and shortly the other lower lobe became involved. The infecting organism was type No. 1 pneumococcus and from the early days of his illness he was very sick. His illness and death cast gloom over the entire institution. The medical staff has lost a very well liked member whose presence will be missed for a long time to come.

On January ninth his funeral services were held in his old home at Bethel, Maine, and he was buried in the cemetery on a low knoll by the river with a distant view of that lovely range of hills which he doubtless loved to look upon when at Bethel.

At a recent meeting of the governing board of the Peter Bent Brigham Hospital the following resolution was adopted:

"The Board of Incorporators learns with deep regret of the death of Dr. Sumner Edwards, House Officer of the Peter Bent Brigham Hospital.

"We deplore the loss to the hospital of his efficient and faithful services, and realize that still greater is the ultimate loss of a man of his promise to his profession and the public. We offer our deep sympathy to his mother."

Henry A. Christian.

\section{JOSEPH HENDLEY TOWNSEND, M.D.}

Dr. Joseph Hendefy Townsend, for the past ten years secretary of the Connecticut State Board of Health and a prominent physician of New Haven, died at his home in that city on January 7 of influenza, culminating in pneu- 